\begin{tabular}{l} 
RCCS \\
\hline Annual Review
\end{tabular}

\section{RCCS Annual Review}

A selection from the Portuguese journal Revista Crítica de Ciências Sociais

5 | 2013

Issue no. 5

\title{
Marginal Gentrification as Emancipatory Practice: An Alternative to the Hegemonic Discourse of the Creative City?
}

\section{Luís Mendes}

Translator. Sheena Caldwell

OpenEdition

Journals

Electronic version

URL: https://journals.openedition.org/rccsar/513

DOI: $10.4000 /$ rccsar.513

ISSN: $1647-3175$

Publisher

Centro de Estudos Sociais da Universidade de Coimbra

Electronic reference

Luís Mendes, "Marginal Gentrification as Emancipatory Practice: An Alternative to the Hegemonic Discourse of the Creative City?", RCCS Annual Review [Online], 5 | 2013, Online since 01 October 2013, connection on 21 September 2021. URL: http://journals.openedition.org/rccsar/513 ; DOI: https:// doi.org/10.4000/rccsar.513 


\section{Luís Mendes}

Institute of Geography and Spatial Planning, University of Lisbon (IGOT-UL), Portugal

\section{Marginal Gentrification as Emancipatory Practice: An Alternative to the Hegemonic Discourse of the Creative City?*}

The main purpose of this article is to present and discuss marginal gentrification as a potential emancipatory practice. This movement is spearheaded by the less privileged sectors of the new middle classes, individuals who are underemployed or in temporary, precarious employment yet still prefer to live in central areas of the city, thus becoming pioneer gentrifiers. They refuse the conventional suburban norms and revanchist city canons, and thus, as a group, they may become an alternative to the dominant narrative presented by the creative city.

Keywords: creative city; cities; gentrification; urban development; cultural policy.

\section{Introduction}

There is an extensive and growing literature on the creative city. Many contributions mention the importance of urban creativity and the cultural industries for urban economic development, whilst others contest the neoliberal ideologies and the effects of segregation, polarisation and social exclusion inherent in the single-minded vision and consensus agenda of the creative city. The transformations in urban landscapes that have accompanied the emergence and development of policies based on Florida's theory $(2002,2004)$ are well known. Various authors have testified to the effects of social polarisation on urban areas in the wake of such policies, namely the ruptures in artistic communities and the uprooting of residents with a lower socioeconomic status as well as of non profit-making organisations headquartered in urban areas recently designated as cultural districts (Booyens, 2012).

Gentrification $^{1}$ is, in the final analysis, one of the harmful effects most widely cited in urban critical theory analyses of the idea and practice of the production of the creative city and the branding of creative districts. As part of creative city policies, urban rehabilitation and regeneration measures - also determined by the need to improve the image of the city and make it more attractive within the strategic framework of global interurban competitiveness - very often imply the eviction of residents with a lower socioeconomic

\footnotetext{
* Article published in RCCS 99 (December 2012).

${ }^{1}$ The main concern of this text is not to problematize the conceptual definition of gentrification, since a large amount of academic literature is devoted to this issue and there is a relative consensus on the core characteristics of the process within the academic community. For a more in-depth examination of the concept, I would refer to the extensive international bibliography discussed in Portuguese in Rodrigues (1992, 2010) and Mendes (2008).
} 
status from central areas, hence condemning them to socio-spatial marginality (Atkinson, 2003; Hutton, 2004; Newman and Wyly, 2006; Lees et. al., 2009; Jacob, 2010; Stolarick et. al., 2010; Parker, 2011; Krätke, 2012).

David Harvey (2010, 2011, 2012), Neil Smith (1996, 2002, 2005) and Jamie Peck (2005) are amongst the authors who stand out for their criticisms of the creative city, framed within the debate on urban policies in the service of neoliberal ideology and the production of the revanchist city. They argue that the "regenerative" discourse of the creative city within the context of urban policies designed to enhance the image of the city, although aimed at embedding the existing population, modernising the economic fabric, increasing employment and economic growth, as well as improving the quality of urban life in general, still, in practice functions as a mechanism for legitimising the established power and mobilising major public investment which, in the final analysis, is diverted away from helping the neediest and serves as a subsidy for the richest (the banks, financial institutions, major economic and civil construction groups, entrepreneurs, politicians, etc.).

State interventions designed to enhance the creative city unleash contradictory mechanisms of expulsion and reappropriation. The new urban policies represent a major orientation towards the market and consumers, to the detriment of the less privileged classes. The authors point out that, to a large extent, the public-private partnerships that are frequently developed in this context constitute a veritable subsidy for the wealthiest and the most powerful companies and organizations, promoting strategies of control, power and domination of urban space, a fundamental condition for perpetuating the reproduction of capital, which is, in turn, essential for the capitalist system of production and consumption. All this takes place at the cost of investments in services for collective consumption. In the final analysis, whilst the attraction and growth provided by gentrification benefit all, the primary gains are reaped by real estate developers, businesses and financial institutions, very often at the cost of uprooting residents and the frailer businesses from the regenerated areas, thus leading to a process of exclusion. Opting for investments that favour the reproduction of capital implies that less attention is paid to the "city of the majority," with particularly serious effects for the neediest areas where the most underprivileged are concentrated (Arantes, 2000). The emergence of the "revanchist city" produced by the neoliberal offensive has been explored by Neil Smith, who removes the social mask of consideration and "institutional beneficence" inherent to these recent real estate products 
of the new urban management, arguing that they promote a logic of social control that favours the reproduction of capital and the ruling classes.

Significant changes in the housing market in inner city areas include the emergence of new real estate developments designed for residential use which have contributed towards creating the phenomenon of "marginal gentrification." This is a movement that involves less privileged sectors of the new middle classes that are attracted by the social and cultural environment of the city centre.

My main aim in this paper is to present and critically discuss marginal gentrification as a potential critical and emancipatory practice, and marginal gentrifiers as a faction of the liberal left within the new middle class which actively and effectively seeks out social (and ethnic) mixing in old, traditional neighbourhoods in the city centre. It may be seen as a critical social movement that provides an alternative to the single-minded, dominant narrative which the creative city represents. Since this is a theoretical and exploratory essay on this issue, without a direct empirical base, the text follows a hypothetical-deductive methodology, and is therefore constructed on the basis of postulates and concepts already established in the literature consulted. By establishing relations between hypotheses, the text presents a possible perspective for interpreting the phenomena in question.

\section{Marginal gentrification as a reaction to modern urban planning}

Nowadays gentrification occurs in various ways in different neighbourhoods in different cities, and therefore involves a variety of protagonists (Lees, 2000). However, in the last 40 years the debate over the definition of the concept has been clear. According to Savage and Warde (1993: 87-88), four processes must combine in order for gentrification to take place: i) the reorganisation of the social geography of the city, involving the displacement, in central areas, of one social group by another with a higher status; ii) a spatial regrouping of individuals with similar lifestyles and cultural characteristics; iii) a change in the built environment and the urban landscape, with the creation of new services and residential rehabilitation that involves important architectural improvements; iv) a change in the land system which, in most cases, leads to a rise in the price of real estate and an "extension in the system of domestic property ownership."

The term gentrification has thus been used to describe the arrival of groups with a higher socioeconomic status, usually the young middle class, in rundown city centre areas. These 
areas then become socially, economically and environmentally enhanced, undergoing a process of filtering up. This constitutes a process of socio-spatial change in which the renovation of residential properties in working class or traditional neighbourhoods by new, relatively well-off residents leads to the displacement of former residents who cannot afford the rising housing costs that accompany this regeneration (Pacione, 2001). Consequently, it is a process by which poor working class neighbourhoods in city centres are renovated by an influx of private capital and middle class landlords and tenants - the same neighbourhoods that had previously experienced disinvestment and the exodus of the middle class. According to Smith (1996), the socio-spatial process entailed by gentrification represents a dramatic and unexpected inversion of what the majority of $20^{\text {th }}$ century urban theories had envisaged as the evolution of the city centre. Having said this, gentrification develops in a variety of socio-spatial and geographical configurations which need to be distinguished, taking into account whether the process is led by flows of investment capital (theories of production and supply) or is constituted as an urban social movement (theories of consumption and demand).

Clay (1979) produced one of the first important studies on gentrification. He developed a stage model for this phenomenon that has been widely accepted by the academic community, typifying a series of aspects ranging from the initial pioneer gentrification phase to the fourth and final phase of maturing gentrification. The final stages in Clay's model which embody the conventional paradigm for what is commonly termed gentrification increasingly involve middle class families or individuals (yuppies and dinks) and real estate developers who aim to capitalise on the "rent gap" ${ }^{2}$ created by the opportunity for investment, thus raising the potential property value in these neighbourhoods as a result of dwellings being bought up for renovation and resale to the wealthier members of the new middle class.

In contrast, in the first stage of gentrification, the social groups who are the pioneers of gentrification have very different characteristics from those which define the typical gentrifiers as members of the new middle class. Firstly, they assert their identity by rejecting "what they interpret as the suburban lifestyle of middle class families" and the major urban redevelopment residential projects; "as an alternative, they value the historic inner city,

\footnotetext{
${ }^{2}$ For a clarification in Portuguese of the concept of "rent gap," see Mendes (2008) and Rodrigues (2010).
} 
which is seen as more 'human' and in which close, neighbourhood relations still exist" (Rodrigues, 2010: 123).

Referring to the pioneer gentrifiers, Rose (1984) developed the concept of the marginal gentrifier. As argued by the author, the process of marginal gentrification, which should be distinguished from mainstream gentrification, generally involves the less privileged sectors of the new middle classes that display a significant gap between their high levels of educational capital and culture and their low level of economic capital. They are individuals who are underemployed or in precarious, temporary employment but prefer to live in central areas of the city, thus becoming pioneer gentrifiers, presumably attracted by the non-conformist lifestyle and the tolerant, socially and ethnically mixed urban environment of city centre neighbourhoods and rejecting the conventional normativity of modern urban planning. Among them, Rose highlights women, students, artists, young couples and singleparent families. There is an obvious parallel between the concept of the marginal gentrifier and the preference given by these individuals to appropriating and residing in the city centre and what Florida $(2002,2004)$ termed the creative class and its proclivity for open, tolerant and plural communities.

Marginal gentrifiers assign great value to the notion of urbanity, and this also results from their valorisation of the city centre as opposed to the idea of social massification and homogeneity introduced by suburban developments and the new real estate products of modern urban planning (many of which are also located in the centre, due to urban restructuring), which, in their opinion, give shape to a model that is the antithesis of urban life in the periphery or in already regenerated urban areas. By valorising the occupation of the city centre, they refute the widely held idea of the "death of the city," and assert their critical opposition to the trend towards the exurbs and the "mass-produced" suburbs which are seen as "anti-city."

Usually seen in a negative, relativized way, i.e. in opposition to the centre, the characteristic features of both the suburbs and the recently restructured urban areas - both examples of modern urban planning - become associated with an entire morphological and territorial field characterised by a social experience and a kind of architecture and spatial organisation that are monotonous, homogenous, lacking in quality, commonplace and amorphous, typically understood as the "sub-urban," or, in other words, inferior to the urban. Modern urban planning is, in effect, associated with a type of extensive urban sprawl, 
resulting either from a highly regulated planning process that produces a very homogenous spatial organisation (hence the idea of monotony), or from more spontaneous forms of urban growth, poorly regulated by the land planning authorities and very often characterised by poor basic infrastructures and limited and inadequate access to better goods, services and facilities.

From this perspective, it is to be expected that for the gentrifiers, as shown by Caulfield's work (1994), the suburbs correspond to a stigmatised socio-spatial representation. They represent exclusion from the urban condition, with high levels of marginality and sociospatial segregation, social anomie and deficit in citizenship. As such, the suburbs offer a precarious existence as a "political arena" for civic and social participation. In contrast, the centre is associated with quality, with a genuine, typical, heterogeneous, different and cosmopolitan environment that is "authentically urban," so that its central condition comes to be perceived as socially distinctive. In fact, the notion of the periphery cannot be defined in itself, in a restricted sense, since it represents realities that are devoid of meaning and value unless they are related to other reference points, namely the centre. Álvaro Domingues states that "it is the extent of its distance from the centre that clarifies the (physical, social, morphological, etc.) peripheral position, and all the more so when the attributes of the centre enjoy greater visibility, positioning, power and distinctiveness" (1994: 5). Therefore "distance" in relation to the centre is also a socially constructed distance which, via the dichotomous image of the centre/periphery, relativizes and simplifies the position of these two types of organisation of metropolitan space. In this dichotomy, the centre is defined in terms of its diversity and density of social relations, intensity of civic life, access to information, and accumulation of cultural, political and economic resources, whereas the suburbs represent the exact opposite. As a social space, the periphery and the suburbs are perceived in terms of their dependent and subaltern relationship to central areas, and from this emerges the distinctiveness of living in the city centre.

The image that prevails in the social construction of the suburbs is that of suburban sprawl, corresponding to increasingly large, rundown, featureless areas, composed of vast unvarying expanses of housing estates (their main function being residential), lacking aesthetic and functional comfort and diversity and with an absence or shortage of public spaces, poor environmental quality, far from the centre and therefore enforcing journeys to and from work that are often incompatible with lifestyles based on what is offered by the 
city centre, and poor infrastructures - in other words, inadequate public and private services and facilities in terms of both quantity and quality. In short, these conditions construct an image of the suburbs as places devoid of urban meaning and identity. The image of the mass-produced suburb as "anti-city," with dysfunctional areas of various kinds, is the main sign of what some authors have warned will be the imminent death of the city. The suburbs generally comprise low quality peripheral housing estates and single-purpose zoning which negate urban quality based on diversity and multifunctionality. Having begun as a means of escaping the confusion of the city, the suburbs have turned into the exact opposite.

Obviously this characterisation of the periphery and the suburbs, although common and widely accepted, far from exhausts the diverse territorial features of the concept, particularly bearing in mind the current logic of urban organisation and structuring as an immediate and systemic component of economic and social restructuring, which deconstructs the simplistic model of the classic metropolis. This discourse is based on the idea of the monocentric metropolis surrounded by a series of concentric circles whose functioning is strictly dependent on the centre. However, it persists in gentrifiers' social representations of modern urban planning.

Therefore, a vision based solely and exclusively on this perspective of a clear centre/periphery dichotomy has little validity and is, to a certain extent, artificial, given that the social construction of the periphery and the suburb, understood in these terms, corresponds in general to a social "preconception." Nevertheless, it clearly predominates in the social representations of gentrifiers, and therefore has a great influence on their symbolic motivational structure and their decision to live in the city centre.

Understanding the suburbs in the general and common sense meaning of a monotonous, low quality way of life based on a lack of quality space, reduced to the most basic function of providing housing and suffering from a general lack of infrastructures, access to goods, services and additional urban facilities which nowadays are part of minimal urban comfort, the gentrifier comes to identify the historic centre as a socially distinctive space that is more compatible with, and conducive to, upward social mobility in the current phase in their life cycle. The marginal gentrifier, according to Walter Rodrigues, also values the old areas of the city "for their distinctive urban planning, typical architecture and traditional historic neighbourhoods, genuine local people and small, local traditional shops" (2010: 123; my italics). All these aspects produce an urban environment that contrasts with the suburbs and 
the mass-produced "socially dehumanising, 'featureless"" qualities of urban development in other words, places where the "urbanalized" production of contemporary space prevails, increasingly dominated by shopping centres (the high churches of consumerism) and private condominiums, amongst other new real estate products to emerge from urban regeneration.

\section{Marginal gentrification as a critical and emancipatory social practice}

Another aspect that is even more important to these reflections - also mentioned by Rodrigues (2010: 123) - and that characterises gentrification in city centres as an emancipatory practice is the fact that marginal gentrifiers value "diversity, tolerance and the freedom of expression of cultures and lifestyles (concepts dear to the official discourse of the creative city) which they associate with the identity of the historic centre, interpreted as an emancipatory, liminal space, in contrast to the greater social, cultural and lifestyle homogeneity and uniformity" of suburban areas and modern urban planning.

Following the same line of thought as Caulfield (1994) and Beauregard (1986), Ley (1996), Butler (1997) and Lees (2004) argue that one of the hallmarks of the new middle class is their ability to explore the emancipatory potential of the city centre to create a new, culturally sophisticated and less conservative urban class. Ley and Mills (1986), in turn, suggest that gentrification in Canadian cities began with a marginal counterculture that was searching for inner city areas that could represent an ideology that was against the prevailing modern ideology of the 1950s and 60s. For example, the authors showed that the gentrifiers living in central areas of the city were more likely to support liberal or minority candidates. In addition, the reformist politicians themselves were often professionals who emerged from neighbourhood activism in city centres.

In his 1994 study, David Ley showed that the main gentrified districts in the three largest cities in Canada - Toronto, Montreal and Vancouver - had a predominantly liberal electorate that believed in socially inclusive measures and reformist policies for equity and multiculturalism. According to the author, these policies featured reforms that aimed to reconcile the management of economic growth with that of human development, and that promoted improvements to public services, particularly housing and transport, and more open urban government, envisaging various forms of empowerment. 
This political identity of the marginal gentrifiers is consistent with their practice. Their move into neighbourhoods does not entail the displacement of long-time residents, since they often occupy houses that are vacant or part of the normal turnover in the neighbourhood rental or sales market, and therefore changes to the housing stock are insignificant. Moreover, once again quoting Rodrigues (2010: 124), "renovation work [...] is almost exclusively undertaken by the gentrifiers themselves, with little recourse to the professional property development sector. The do-it-yourself nature of gentrification in this initial phase is inherent to the nature of the process itself and the lifestyles of its protagonists," mainly young adults from intellectual and artistic professions or other creative occupations associated with urban regeneration and culture, architecture and design. This being the case, it is not unexpected that only small-scale renovations take place at this stage, in which rehabilitation work motivated by "love of one's first home" usually predominates.

All these factors explain the occasional and fragmented involvement in the process of gentrification in local neighbourhoods. Typically, gentrification begins with some families seeking small spaces available in rundown neighbourhoods that offer environments suitable for alternative lifestyles (for example, avant-garde artists or gay and lesbian communities). This first wave corresponds to an embryonic process of gentrification, according to Mendes (2008), which develops slowly and intermittently, manifesting itself in urban space in a random and fragmented manner, on a small scale circumscribed to a few homes or, at most, a few blocks in a neighbourhood. This initial stage of gentrification, observable in areas in the centre of Lisbon and other cities in southern Europe, must be distinguished from the patterns of gentrification as a global urban strategy in the service of the revanchist city and the neoliberal offensive that underlies it, which is more widespread in cities in the AngloSaxon world.

This multifaceted perception of the process emphasises the importance of the temporal and spatial context for understanding the complexity and specificity of the geography of gentrification in southern European cities and warns against the assumption that conventional theory can be directly applied to all levels of the global urban hierarchy. This sensitivity to context is displayed in an article by Smith and Graves (2005), who use the city of Charlotte, North Carolina, as a case study to illustrate a geography of gentrification in which the motivations/explanatory factors and characteristic trends in each stage do not fit within the conceptual framework of traditional theories of the phenomenon. In this 
medium-sized U.S. city, gentrification was introduced for the first time in the early 1970s, when business leaders recognised the importance of revitalising the central area of the city in a way that would reinforce its corporate identity and allow for strategic management of the city image on the basis of objectives that were conducive to this. The production of gentrification in this context, contrary to what might have been expected, was characterised by the complete absence of marginal gentrifiers and the traditional groups of urban pioneers, leading some theorists to question the validity of the traditional stage model advocated by Clay (1979). In addition to providing an analysis of gentrification in terms of the urban hierarchy (and on a regional scale), something that had been neglected for a long time, the article helped to introduce a critical approach that was more flexible and contextual in terms of understanding the causality of gentrification as a process.

Collectively, traditional research on gentrification has produced two main principles which are central to the most important urban studies of this process. Firstly, the process develops in a series of temporally and spatially specific phases as it advances in urban space (the pioneer study by Clay, 1979). Secondly, its causality derives to a great extent from factors associated with either supply (theories of production) or demand (theories of consumption) (Ley, 1996; Smith, 1996; Lees, 1994; Lees, Slater and Wyly, 2008). These explanations have tended to diverge, with each seeking to impose the supremacy of one sphere over the other in studying the process of gentrification.

Supply-based theories, which are markedly Marxist-influenced, have sought to emphasise the importance of capital and the various institutional agents (the state, local authorities, banks and other financial institutions) in the process of restructuring urban space, whereas demand-based theories emphasise consumption rather than production in the housing and urban land market. In short, the theories that uphold the primacy of production derive the process of gentrification from the flow and circulation of capital in urban areas, seeking to explain this process by the devaluation of urban land and the generation of returns by new investment. Leading contributions include the work of Neil Smith and David Harvey in the 1970 s and 80s.

In turn, the theories that focus on consumption see gentrification as a direct consequence of changes in the demographic and social structure of populations, the lifestyle of certain sectors of the middle class and the values and patterns of consumption associated with this. They argue that these changes are framed within the emergence of a post-modern social 
and urban condition, whose signs and manifestations are difficult to ignore, as demonstrated in the work of Chris Hamnett, David Ley and Tim Butler.

Whilst considerable attention has been paid to the analysis of the most recent stages in the process (Hackworth and Smith, 2001) and to exploring the intersection and complementarity of theories of production and consumption, explicit attention has very rarely been paid to the argument that the stages of gentrification and their respective causal dynamics are shaped differently according to the spatial scale and urban context in which they take place. Moreover, there remains a tendency to assume that the motivations, mechanisms, actors and phases in gentrification identified in global cities have parallels in smaller cities. However, a still emerging literature suggests that there is a pressing need for more sensitive geographical analyses which demonstrate that "gentrification is not the same everywhere" and that in some cases the differences may be enough to call into question the accepted theoretical models (Lees, 2000).

The muddled nature of the concept of gentrification is particularly evident in light of a geographical perspective. In fact, the various processes commonly referred to as gentrification in the literature are very useful in demonstrating contrasting geographies (Van Criekingen and Decroly, 2003). On the one hand, there is a revanchist perspective on the successive flows and violent and contested advances on the frontiers of gentrification in U.S. city centres that views them as expressions of anti-urban development, and therefore tends towards an interpretation of cause and effect that focuses on socio-spatial conflicts and unequal and fragmented urban development, both generated by the global circuits and cyclical movements of capital. On the other hand, Canadian and European analyses have focused more on the contribution made by gentrification to the creation of emancipatory, tolerant and socially diverse urban environments in city centres. Analyses of causality in the latter case are inclined to emphasise individual actions and choices (agency) within the context of a concern on the part of public policies and municipal authorities to create quality urban space for all (in the Lefebvrian sense of the right to the city and urban revolution). The arguments and public policies that promote and recognise gentrification as a positive process for neighbourhoods contrast with those which view it as a socio-spatial phenomenon that has harmful effects on the social environment of these urban areas. These two discourses on the effects of the process, which dominate academic literature on 
gentrification, are referred to by Lees $(2000,2004)$ as the "emancipatory city thesis" and the "revanchist city thesis," respectively.

The emancipatory city thesis is largely implicit in the literature on gentrification that addresses the gentrifiers and their forms of agency as social actors spearheading the process, as for example in the work of David Ley $(1994,1996)$ and Tim Butler (1997). However, it is in the work of Jon Caulfield (1994) that this argument is effectively acknowledged by being stated explicitly. It revives an old thesis in which the city is portrayed as an emancipatory or liberating space. Caulfield's analysis (1994) centres on gentrification in Toronto, Canada, and describes the unfolding of this complex process in the inner city as an emancipatory social movement and gentrification itself as a critical and emancipatory social practice. According to this argument, gentrification is a process that unites people in the city centre and creates opportunities for social interaction, promoting tolerance and cultural diversity. It is seen as a liberating experience, both for the gentrifiers and for those who come into contact with them. Caulfield argues that encounters between "different" people in the city are inherently liberating, providing opportunities for subverting the prevailing consumer culture and creating social activities that expose the contradictions of capitalist space, thus opening up opportunities for developing alternative urban projects.

\section{Diversity and social mixing in the creative city: Contradictions between the discourse and practice of the gentrifier}

Gentrification has been associated with social movements in the centre which support diversity, difference and social mixing. According to a longstanding tradition of research into the process, the "liberal" desires of the new middle classes for the difference and diversity in/of the city are the key to explaining the gentrification process and for creating a more diverse and tolerant city. They draw attention to the fact that the benefits of socially mixed urban communities have become an undeniably important subject in urban political discourse. Sociocultural diversity has always been a leitmotiv of new demands for housing in historic and traditional city centre neighbourhoods. One of the best advantages afforded by life in the heart of the city is known to be the exposure to social, cultural and ethnic diversity. The diverse urban environment is a constant source of stimulation and renewal and a reminder of the cultural relationality from which identities and lifestyles are constructed (Lees, 2008). 
In a certain way, this "spirit of diversity" has been associated, even historically, with the particular capacity of cities to be creative and generate innovation (Hall, 2000). Spurred by the discourse of the creative city, the issue of social mixing has recently moved to the forefront of the debate on gentrification (Bridge et al., 2012). To some extent, this has been stimulated by neoliberal urban policies promoting social mixing. However, recent research has revealed the inability of gentrified neighbourhoods to remain socially mixed, leading theorists, technicians and specialists to rethink the association between gentrification, displacement and residential segregation. At present there is no evidence for the generalized assumption that the policy of (marginal) gentrification will help extend and promote social mixing, and therefore increase the social capital and social cohesion of urban communities. The work of Rose (2004) and Davidson (2010) in particular shows that little evidence has been found to prove that significant interactions take place between populations, and that shared perceptions of community between the gentrifiers and the local population are very rare. Davidson, for example, argues that the specific nature of the new forms of gentrification (such as private luxury condominiums) have played an important role in the emergence of what he calls "social tectonics," consequently influencing urban spatial organisation towards growing segregation on a micro scale and the fragmentation of contemporary urban space. This is also because the geography of the gentrifiers' sociabilities tends to take the form of enclaves that are disconnected in social-spatial terms from the surrounding social fabric and contiguous areas.

There have been a number of studies on social interaction in these neighbourhoods which point to the fact that social networks amongst neighbours tend to be socially segregated, especially in terms of socioeconomic status and ethnicity. An influx of well-off residents in an underprivileged middle class neighbourhood may not enhance social cohesion, since the contact between individuals/families with low and higher incomes tends to be superficial at best, and frankly hostile at worst (Osman, 2011). In their discourse, the new middle classes reveal a desire for diversity and difference, but in their everyday practices they tend towards self-segregation. The notions of diversity lie only in the socio-spatial representations of the gentrifiers - in their self-image as cosmopolitan citizens - rather than in practical actions, reflecting a form of defining and distinguishing themselves as a specific class faction rather than the actual social appropriation of space in a tolerant, open and plural way. There has been no transfer of social capital from the groups with a higher socioeconomic status to 
those with a lower status, nor any other of the results expected from the introduction of a middle class population into rundown central city neighbourhoods. In part, this is due to the transience of the new residents, but also to the spatially segregated nature of the new real estate urban developments located next to rundown communities deprived of any sociospatial continuity. As Davidson (2010) argues, the people in the two lifeworlds rarely cross paths. They do not work in the same places or use the same form of transport. They do not go to the same restaurants or public places. They have different family structures. They also have different expectations and aspirations with regard to the community and the "supposed" social mix, an indicator of the diversity and heterogeneity essential to embedding the creative class. According to the empirical data that Davidson gathered on local relations between the gentrifiers who moved into a neighbourhood and the long-term residents, social ties rarely crossed class and ethnic boundaries, and the social networks in the neighbourhoods seemed impermeable to the changes taking place around them, with confrontations also registered between the norms of the gentrifiers and those of the longterm residents. Along the same lines, Loretta Lees (2008) offers a biting critique of social mix policies based on the rhetoric of gentrification and their actual ability to produce genuinely inclusive urban environments.

To a large extent, the emancipatory thesis reflects the ideologies associated with marginal, pioneering gentrification. There is a significant body of arguments on gentrification as a liberating, critical and countercultural process. However, a temporal dimension underlies our understanding of how the process advances. For the approach that considers the pioneering phase of gentrification, this presents more positive aspects and possibilities for alternative urban development (the centre as liminal space) than the later, more aggressive phases of the process.

\section{Final considerations: The commodification of difference and tolerance in the creative city}

The ambiguity and contradictions between the discourse and practice of gentrification that promotes social mixing and "difference," which is based on an emancipatory understanding of urban space, reflect the contradictions evident in the programme for creative cities launched by Florida's thesis $(2002,2004)$. Put simply, difference is "included" in the discourse of the creative city but in a very limited way: it is not implemented in practical terms, and is very often short-sighted in its view of the real social and housing conditions of 
minority groups. There are two aspects to this contradictory treatment of "difference" in the discourse of urban planning associated with creative policies. On the one hand, "difference" is appropriated by urban cultural policy with the aim of transforming it into a positive marketing point to sell cities as good places to live in, work and visit. This represents the neoliberalisation of difference, in the opinion of Catungal (2009), to the extent that the concept is instrumentally manipulated by territorial marketing campaigns to forge an idea of multicultural urban life which is attractive to young professionals. On the other hand, the negative impacts of creative city planning on forgotten communities and people remain largely unacknowledged by advocates of the ideology of the creative city (Barnes et. al., 2006; Zimmerman, 2008).

In his powerful and frequently quoted critique of the creative city, Peck (2005) observes that the cult of creativity in urban politics reproduces boosterism agendas, supporting previous forms of urban entrepreneurialism. The effect, observes the author, is to reinvent cities as growth machines and places for the accumulation of capital, and to focus on attracting the new middle classes as the key factor in more competitive urban economies, embracing the culture of the new capitalism or, following the same line of thought but in the words of Allen Scott (2006), the cultural economy of late capitalism.

One particular impasse for urban critical theory in general is that the political agendas for the creative city continue to use the liberal forms of multiculturalism as a framework for narrating/forging a glocal identity in conjunction with new forms of transnational, cosmopolitan and creative citizenship, a common form of constructing hegemony under transnational capitalism. There is growing recognition that, on an urban level, multiculturalism and diversity should be boosted to attract talent and promote creativity and innovation. Difference is commercialised, reduced to a commodity that can be deployed to attract human capital, tourists and investment and promote a vibrant urban economy (Okano and Samson, 2010). Emphasis is placed on creating bohemian neighbourhoods and on the commodification and celebration of difference through public events such as festivals and public art (McGuigan, 2009; Vivant, 2010). In this respect, it is important to explore whether the cultural landscapes that are vital to the creative city really serve to promote particular memories to the detriment of others and, if so, how this is being done. Moreover, both the forms of public urban art and the use of the built heritage, as well as other artistic expressions that flood urban landscapes, cannot be viewed purely in terms of their economic 
function as mere commodities for a creative class, serving the neoliberal trade interests of the city-enterprise. In fact, they are deeply political manifestations that enable the negotiation of difference within the context of increasingly multicultural cities (Scott, 2006; Pratt, 2008, 2010, 2011).

In many cases, the appropriation of ethnic and cultural diversity to sell the creative city is an expression of power and privilege whereby practices of "difference" and "tolerance" are drained of political and cultural meaning. However, this tendency also suggests that the commodification of difference may potentially provide an opening for more critical forms of multiculturalism to produce, appropriate, experience and manage contemporary urban space, recognising that these processes involve not only control, but also resistance. This, in my view, is the first step towards reclaiming diversity in the contemporary urban society of the creative city, in order to reinvent the narrative codes and destabilise the conventional theories of the city, whilst also allowing for the emergence of new ways of seeing that enable a more plural, open, democratic and critical urban space to be produced.

\section{Translated by Sheena Caldwell}

Revised by Teresa Tavares

\section{References}

Arantes, Otília (2000), "Uma estratégia fatal. A cultura nas novas gestões urbanas," in Otília Arantes, Carlos Vainer \& Ermínia Maricato (eds.), A cidade do pensamento único. Desmanchando consensos. Petrópolis: Editora Vozes, 11-74.

Atkinson, Rowland (2003), "Domestication by Cappuccino or a Revenge on Urban Space? Control and Empowerment in the Management of Public Spaces," Urban Studies, 40(9): 1829-1843.

Barnes, Kendall; Waitt, Gordon R.; Gill, Nicholas J.; Gibson, Christopher R. (2006), “Community and Nostalgia in Urban Revitalisation: A Critique of Urban Village and Creative Class Strategies as Remedies for Social Problems," Australian Geographer, 37(3): 335-354.

Beauregard, Robert (1986), "Gentrification, Strategic Initiatives, and the Left," Alternatives, 4: 3-14.

Booyens, Irma (2012), "Creative Industries, Inequality and Social Development: Developments, Impacts and Challenges in Cape Town," Urban Forum, 23: 43-60.

Bridge, Gary; Butler, Tim; Lees, Loretta (2012), Mixed Communities: Gentrification by Stealth? London: Polity Press.

Butler, Tim (1997), Gentrification and the Middle Classes. Aldershot: Ashgate.

Catungal, John (2009), "Contesting the Creative City: Race, Nation, Multiculturalism," Geoforum, 40: 701-704. 
Caulfield, Jon (1994), City Form and Everyday Life. Toronto's Gentrification and Critical Social Practice. Toronto: University of Toronto Press.

Clay, Phillip (1979), Neighborhood Renewal: Middle-Class Resettlement and Incumbent Upgrading in American Neighborhoods. Lexington, Massachusetts: D.C. Health.

Davidson, Mark (2010), "Love thy Neighbour? Social Mixing in London's Gentrification Frontiers," Environment and Planning A, 42(3): 524-544.

Domingues, Álvaro (1994), "(Sub)úrbios e (Sub)urbanos: O mal estar da periferia or a mistificação dos conceitos?" Revista da Faculdade de Letras da Universidade do Porto - Geografia, 8/9: 5-18.

Florida, Richard (2002), The Rise of the Creative Class - And How It's Transforming Work, Leisure, Community and Everyday Life. New York: Basic Books.

Florida, Richard (2004), Cities and the Creative Class. New York: Routledge.

Hackworth, Jason; Smith, Neil (2001), "The Changing State of Gentrification," Tijdschrift voor Economische en Sociale Geografie, 22: 464-477.

Hall, Peter (2000), “Creative Cities and Economic Development," Urban Studies, 37(4): 639-649.

Harvey, David (2010), The Enigma of Capital and the Crisis of Capitalism. Oxford: Oxford University Press.

Harvey, David (2011), Le capitalisme contre le droit à la ville: Néolibéralisme, urbanisation, résistances. Paris: Éditions Amsterdam.

Harvey, David (2012), Rebel Cities: From the Right to the City to the Urban Revolution. London: Verso.

Hutton, Thomas (2004), "The New Economy of the Inner City," Cities, 21(2): 89-108.

Jacob, Doreen (2010), "Constructing the Creative Neighborhood: Hopes and Limitations of Creative City Policies in Berlin," City, Culture and Society, 1(4): 193-198.

Krätke, Stefan (2012), "The New Urban Growth Ideology of Creative Cities," in Neil Brenner, Peter Marcuse \& Margit Mayer (eds.), Cities for People, Not for Profit. Critical Urban Theory and the Right to the City. London: Routledge, 138-149.

Lacoste, Yves (2003), De la géopolitique aux paysages : Dictionnaire de la géographie. Paris: Armand Colin.

Lees, Loretta (1994), "Rethinking Gentrification: Beyond the Positions of Economics or Culture," Progress in Human Geography, 18(2): 137-150.

Lees, Loretta (2000), "A Reappraisal of Gentrification: Towards a Geography of Gentrification," Progress in Human Geography, 24(3): 389-408.

Lees, Loretta (2004), "The Emancipatory City: Urban (Re)Visions," in Loretta Lees (ed.), The Emancipatory City? Paradoxes and Possibilities. London: Sage, 3-21.

Lees, Loretta (2008), "Gentrification and Social Mixing: Towards an Inclusive Urban Renaissance?" Urban Studies, 45(12): 2449-2470.

Lees, Loretta; Slater, Tom; Wyly, Elvin (2008), Gentrification. London: Routledge.

Lees, Loretta; Imrie, Rob; Raco, Mike (2009), Regenerating London. Governance, Sustainability and Community in a Global City. London: Routledge.

Ley, David (1994), "Gentrification and the Politics of the New Middle Class," Environment and Planning D: Society and Space, 12(1): 53-74.

Ley, David (1996), The New Middle Class and the Remaking of the Central City. Oxford: Oxford University Press. 
Ley, David; Mills, Caroline (1986), "Gentrification and Reform Politics in Montréal 1982," Cahiers de Géographie du Québec, 30(81): 419-427.

Mendes, Luís (2008), "A nobilitação urbana no Bairro Alto: Análise de um processo de recomposição socio-espacial." Masters thesis submitted to the Geography Department, Faculty of Arts, University of Lisbon.

McGuigan, Jim (2009), "Doing a Florida Thing: The Creative Class Thesis and Cultural Policy," International Journal of Cultural Policy, 15(3): 291-300.

Newman, Kathe; Wyly, Elvin (2006), "The Right to Stay Put, Revisited: Gentrification and Resistance to Displacement in New York City," Urban Studies, 43(1): 23-57.

Okano, Hiroshi; Samson, Danny (2010), "Cultural Urban Branding and Creative Cities: A Theoretical Framework for Promoting Creativity in the Public Spaces," Cities, 27(5): 510-515.

Osman, Suleiman (2011), The Invention of Brownstone Brooklyn. Gentrification and the Search for Authenticity in Postwar New York. Oxford: Oxford University Press.

Pacione, Michael (2001), Urban Geography. A Global Perspective. London: Routledge.

Parker, Simon (2011), Cities, Politics and Power. London: Routledge.

Peck, Jamie (2005), "Struggling with the Creative Class," International Journal of Urban and Regional Research, 29(4): 740-770.

Pratt, Andy (2008), "Creative Cities: The Cultural Industries and the Creative Class," Geografiska Annaler, 90(2): 107-117.

Pratt, Andy (2010), "Creative Cities: Tensions within and between Social, Cultural and Economic Development. A Critical Reading of the UK Experience," City, Culture and Society, 1(1): 13-20.

Pratt, Andy (2011), "The Cultural Contradictions of the Creative City," City, Culture and Society, 2(3): 123-130.

Rodrigues, Walter (1992), Retorno à cidade e emergência de novos estilos de vida. O fenómeno "gentrification" como exemplificação. Lisbon: ISCTE.

Rodrigues, Walter (2010), Cidade em transição. Nobilitação urbana, estilos de vida e reurbanização em Lisboa. Oeiras: Celta Editora.

Rose, Damaris (1984), "Rethinking Gentrification: Beyond the Uneven Development of Marxist Urban Theory," Environment and Planning D: Society and Space, 2(1): 47-74.

Rose, Damaris (2004), "Discourses and Experiences of Social Mix in Gentrifying Neighbourhoods: A Montreal Case Study," Canadian Journal of Urban Research, 13(2): 278-316.

Savage, Mike; Warde, Alan (1993), Urban Sociology, Capitalism and Modernity. London: Macmillan.

Scott, Allen (2006), "Creative Cities: Conceptual Issues and Policy Questions," Journal of Urban Affairs, 28(1): 1-17.

Smith, Neil (1996), The New Urban Frontier. Gentrification and the Revanchist City. London: Routledge.

Smith, Neil (2002), "New Globalism, New Urbanism: Gentrification as Global Urban Strategy," Antipode, 34(3): 427-450.

Smith, Neil (2005), "El redimensionamiento de las ciudades: la globalización y el urban planning neoliberal," in David Harvey \& Neil Smith (eds.), Capital financiero, propiedad inmobiliaria y cultura. Barcelona: Universitat Autònoma de Barcelona, 59-78. 
Smith, Heather; Graves, William (2005), "Gentrification as Corporate Growth Strategy: The Strange Case of Charlotte, North Carolina and the Bank of America," Journal of Urban Affairs, 27(4): 403418.

Stolarick, Kevin; Hrcas, Brian J.; Florida, Richard (2010), "Occam's Curse, Dialectics, and the Creative City," City, Culture and Society, 1(4): 175-177.

Van Criekingen, Mathieu; Decroly, Jean-Michel (2003), "Revisiting the Diversity of Gentrification: Neighbourhood Renewal Processes in Brussels and Montreal," Urban Studies, 40(12): 2451-2468.

Vivant, Elsa (2010), "The (re)Making of Paris as a Bohemian Place?" Progress in Planning, 74: 107152.

Zimmerman, Jeffrey (2008), "From Brew Town to Cool Town: Neoliberalism and the Creative City Development Strategy in Milwaukee," Cities, 25(2): 230-242. 